\title{
Using Risk Assessment and Management Approaches to Develop Cost-Effective and Sustainable Mine Waste Management Strategies
}

\author{
Theodora Karachaliou ${ }^{1}$, Vasileios Protonotarios ${ }^{2}$, Dimitris Kaliampakos ${ }^{1}$ and Maria Menegaki ${ }^{1, *}$ \\ 1 School of Mining and Metallurgical Engineering, National Technical University of Athens, Zografou 15780, \\ Greece; dkarachaliou@metal.ntua.gr (T.K.); dkal@central.ntua.gr (D.K.) \\ 2 Lavrion Technological and Cultural Park, Lavrion 19500, Greece; btproto@yahoo.com \\ * Correspondence: menegaki@metal.ntua.gr; Tel.: +30-210-7722209
}

Academic Editor: Michele Rosano

Received: 30 September 2016; Accepted: 14 November 2016; Published: 22 November 2016

\begin{abstract}
Soil contamination by mine wastes is an enormous challenge for both mining companies and competent authorities. Mine wastes are usually considered a major source of impacts on human health and the environment. Thus, the prevailing strategy is to reduce or completely remove the contaminants of concern through appropriate in situ or ex situ remediation techniques. Nonetheless, today's mine waste may become tomorrow's ore. In order to keep this option open, however, several things need to change in the concept and practice of mine waste management. This paper presents a case study from Greece, where mine waste (mainly metallurgical slags) have been disposed of, posing excess risks to human health and the environment. Complete restoration of the site would not only be cost-prohibitive but would also eliminate any possibility of future exploitation of contained resources. Considering both the protection of human health and the environment and the storage of waste for future use, a risk assessment and management approach was adopted that allowed the selection of cost-effective measures in order to: eliminate health hazards, re-use the site for recreational purposes, and secure the opportunity for resource recovery in the future.
\end{abstract}

Keywords: health risk assessment/management; site contamination; heavy metals; cost and risk minimization; sustainable mine waste management

\section{Introduction}

Mining and metallurgical activities produce a considerable amount of waste that contains metals and metalloids, usually in high concentrations. As a result, mining waste facilities are associated with soil contamination posing a significant risk to both human health and the environment. According to a recent report produced by the JRC in collaboration with the EEA [1] the number of potentially contaminated sites in Europe is estimated at 2.5 million, while the identified ones are around 342,000. Moreover, data collected by the European Soil Data Center of the European Commission using the European Environment Information and Observation Network for soil (EIONET-SOIL) suggest that the mining sector is responsible for around 7\% of soil contamination in Europe [2]. The degree of impact depends on the characteristics of the ore and of the waste, the scale of mining, and the mining and beneficiation methods used to recover the valuable minerals.

Some countries have adopted standards related to threshold or target maximum values of certain contaminants in soil. Yet, in many countries, including Greece, no such national standards have been imposed. Furthermore, a point of concern is that the respective standards differ from country to country, according to each nation's priorities [3]. For example, the United Kingdom has established limits based on the "end-use" of the site, while the German policy is targeted to the groundwater protection and the Dutch standards mainly address the multifunctionality of soil. 
Despite the differences existing between regulations, countries' remediation strategies have one characteristic in common: they focus almost solely on the elimination of the source of the hazard. That is, soil clean-up is required by means of treatment technologies available (e.g., chemical extraction and soil washing, immobilization, soil handling, etc.). Nevertheless, clean-up costs are often very high, as shown in Table 1.

Table 1. Costs of remediation technologies for soil contamination.

\begin{tabular}{ccc}
\hline General Category & Remediation Technology & Indicative Unit Price (€) \\
\hline Excavation and containment & Excavation and disposal to landfill & $74 / \mathrm{m}^{3}$ \\
\hline \multirow{2}{*}{ In situ physical containment by } & Engineering capping & $22-44 / \mathrm{m}^{2}$ \\
means of engineering systems & Encapsulation (shallow cut-off wall) & $59-89 / \mathrm{m}^{2}$ \\
& Encapsulation (deep cut-off wall) & $104-178 / \mathrm{m}^{2}$ \\
\hline & Bioremediation & $52-67 / \mathrm{t}$ \\
& Vitrification & $59 / \mathrm{t}$ \\
Treatment & In-situ vitrification $(5 \mathrm{t} / \mathrm{h})$ & $225-319 / \mathrm{t}$ \\
& Soil washing & $45-52 / \mathrm{t}$ \\
& In situ chemical oxidation & $59-119 / \mathrm{m}^{3}$ \\
& Soil washing ex situ & $43-171 / \mathrm{t}$ \\
& Stabilization/Solidification ex situ & $45-170 / \mathrm{t}$ \\
& Landfarming & $48 / \mathrm{t}$ \\
& Pump and treat & $30-120 / \mathrm{t}$ \\
\hline
\end{tabular}

Source: CLARINET [4] compiled by Kaliampakos et al. [5].

U.S. EPA reports indicate similar remediation costs between 5 USD up to 250 USD per ton of soil, depending on the selected method and the target remediation values [6]. Even with the lower cost, the management of contaminated sites is quite expensive. For instance, it is estimated that European countries should spend around 6 billion Euros per year to deal with contaminated land [1], and the mining sector's contribution to the problem is significant.

At the same time, however, these sites contain useful materials that might be recovered under specific circumstances. To wit, the continuous resource depletion that creates the need for the exploitation of 'poor' ores on one hand and the rapid technological evolution on the other hand may transform existing mine waste dumps into the mines of the future at a known location. This prospective should not be ignored, since the quantities of deposited materials around the world are significant. For instance, according to Kapur and Graedel [7], the quantity of copper located in all kinds of waste repositories is about 300 million tons, an amount corresponding to more than $30 \%$ of the remaining reserves in known ores [8].

Considering the abovementioned remarks, a complex situation arises in the case of contaminated mined sites, having serious economic, environmental, social, and political implications. On the one hand, there is the need to protect human health and ecosystems from harms related to past mining activities at an affordable cost for the society. On the other hand, remediation measures should be implemented in a way that would allow for the potential 'ore' to be mined in the future. In such cases, a risk-based approach may be quite effective in providing an environmentally sound and economically viable solution without jeopardizing the opportunity to recover valuable resources in the future from today's waste. Risk-targeted methodologies examine the chain of "Hazard $\rightarrow$ Pathway $\rightarrow$ Target" and aim to break the links [9]. In this way, risks can be managed in many ways, e.g., they can be eliminated, transferred, reduced, encapsulated, or retained with respect to an acceptable risk level taking into consideration critical factors of the problem under investigation (e.g., environmental pollution, finance, regulation, social effect, etc.).

By focusing on the risk-based assessment, this paper aims to offer a different view on the issue of mine waste management. To this end, a heavily contaminated area in Greece, for which there are limited remediation funds available, is used as case study. More specifically, the paper illustrates 
the effectiveness of risk assessment and risk management techniques as a means to implementing immediate, cost effective actions that: (a) minimize health hazards (i.e., cut the pathways via which the hazards are transmitted); (b) allow the safe use of the site for recreational purposes; and (c) facilitate the reverse process in which the wastes could be mined and used as valuable materials in the future. The rest of the paper is structured as follows: Section 2 provides background information with respect to the site used as case study. Section 3 illustrates the risk assessment methodology followed. Section 4 presents the results of the analysis. Finally, Section 5 summarizes the main conclusions drawn from this work.

\section{The Kavodokanos Site}

\subsection{General Information}

The "Kavodokanos" site is located next to the old metallurgical complex of the former "Compagnie Francaise des Mines du Laurium", adjacent to the city of Lavrion, about $60 \mathrm{~km}$ from the Athens metropolis. The broader area is characterized by a unique historical and industrial heritage, since the mining and metallurgical operations, related to the exploitation of the silver and lead ores, started in the year 3000 BC and ended in 1989 [10-12]. These ores supported the Golden Age of Athens, and thousands years later contributed to the development of Greek industry. Nevertheless, the intensive and long term mining and metallurgical activities have resulted in serious pollution problems affecting the broader area of Lavrion and the local community.

Solid wastes from the mining and minerals industry were traditionally disposed of, usually in the form of large heaps (dry waste e.g., slags) or slime dams (wastes in slurry form). The area in and around the city of Lavrion is highly polluted and pollution consists of by-products of the industrial activity deposited uncontrollably, such as slags coming from the smelting process of silver-lead ores and various sulfur compounds waste (known as B.P.G. blende-sphalerite, pyrite, galena) derived from the metallurgical beneficiation process of flotation [11-13].

According to previous records and research projects (e.g., [13]), within the borders of the Kavodokanos site, mainly metallurgical slags have been deposited. Those wastes are relatively 'young', since they have been gradually dumped during the last 150 years. Another point of concern is that several sandblasting activities have taken place on site during the last 20 years [13], utilizing the existing slags as abrasive material. Thus, there is a differentiation in granulometry of wastes, since slags, as a by-product of sandblasting process, are much finer materials than typical metallurgical slags.

The nature of the wastes has been confirmed by site investigations. Typical metallurgical slags for the area present black to grey colors and, in rare cases, yellow to brown-yellow colors, indicating the presence of flotation residues. Finally, at several locations, inert wastes, coming from construction activities, have been deposited, while bulky municipal wastes are also present. The disposal site occupies an area of approximately $104,000 \mathrm{~m}^{2}$ and contains approximately $200,000 \mathrm{~m}^{3}$ of waste as estimated by means of geophysical techniques.

\subsection{Sampling Regime}

The research team investigated the site to assess the extent and severity of pollution. The site investigation included soil sampling from 25 locations from the topsoil $(0-0.30 \mathrm{~m})$. Sampling locations were selected so as to cover the largest possible area and reassure the representativeness of the samples. Bearing in mind the gradual deposition of different types of waste through the last 150 years, mixing of samples was avoided and every single solid sample was subjected to chemical analysis. Furthermore, for purposes of quality control, "blind" samples were collected from locations where no depositions were observed and native soil is visible.

Samples were stored and preserved for laboratory determinations by implementing ISO 18512/2007. For purposes of metals and metalloids determination, each sample was prepared for chemical analysis according to European Standard Final Draft prEN13657. Further analysis of 
each element was conducted according to DIN EN ISO 11885 and DIN EN ISO 17294, by utilizing Inductively Coupled Plasma Spectrometry (ICP-OES-Prodigy-Teledyne, Leeman Labs, 110 Lowell Road, Hudson, NH, USA), Inductively Coupled Plasma Mass Spectrometry (ICP-MS) and Atomic Absorption Spectroscopy (Polarized Zeeman Atomic Absorption Spectrophotometer Z2000 series, AAS-Hitachi, Tokyo, Japan).

Following the aforementioned procedures, the elements Arsenic (As), Cadmium (Cd), Copper $(\mathrm{Cu})$, Lead $(\mathrm{Pb})$, Iron $(\mathrm{Fe})$, Zinc $(\mathrm{Zn})$, and Chromium $(\mathrm{Cr})$ were measured in each sample. Each measurement was replicated twice, for different samples and the difference between the two samples was less than $5 \%$.

The particular elements were selected based on the previous experience of the research team, with respect to waste sampling and measurement in the broader area of Lavrion. Furthermore, relevant literature has indicated those metals and metalloids as the most common among the metallurgical waste $[11,12,14,15]$.

In order to clarify the origin of the waste (i.e., slags or flotation waste), apart from pollutants concentrations, the determination of additional physicochemical characteristics of the soil was necessary. In view of that, $\mathrm{pH}$ (ISO 6588-Mettler-Toledo $\mathrm{pH}$ Analyst) and total sulfur content (LECO SC 144DR) were specified.

Chemical analysis results are presented in Table 2.

Table 2. Chemical Analysis Results (values in mg kg-1 except from $\mathrm{pH} \kappa \alpha \iota \mathrm{S}$ ).

\begin{tabular}{|c|c|c|c|c|c|c|c|c|c|}
\hline No. & As & $\mathrm{Cd}$ & $\mathrm{Cu}$ & $\mathrm{Pb}$ & $\mathrm{Fe}$ & $\mathrm{Zn}$ & $\mathrm{Cr}$ & $\mathrm{S}(\%)$ & $\mathrm{pH}$ \\
\hline 1 & 650 & 18 & 77 & 9768 & 209,600 & 36,090 & $<0.1$ & 1.2 & 6.1 \\
\hline 2 & 543 & 15 & 104 & 9467 & 212,512 & 34,657 & $<0.1$ & 1.1 & 6.0 \\
\hline 3 & 925 & $<0.1$ & 1389 & 11,260 & 141,720 & 42,250 & 32 & 1.7 & 6.2 \\
\hline 4 & 951 & $<0.1$ & 1424 & 10,068 & 167,340 & 44,524 & 27 & 1.7 & 6.1 \\
\hline 5 & 1120 & $<0.1$ & 3080 & 15,160 & 150,400 & 54,610 & $<0.1$ & 2.1 & 6.7 \\
\hline 6 & 1008 & $<0.1$ & 2912 & 15,945 & 17,065 & 57,612 & $<0.1$ & 1.9 & 6.5 \\
\hline $7 *$ & $<0.1$ & $<0.1$ & $<0.1$ & 515 & 20,990 & 1975 & 25 & 0.025 & 7.4 \\
\hline $8^{*}$ & $<0.1$ & $<0.1$ & $<0.1$ & 424 & 21,512 & 2001 & 18 & 0.023 & 7.6 \\
\hline 9 & 2042 & 26.4 & 726 & 11,305 & 174,000 & 54,460 & 143 & 1.8 & 6.4 \\
\hline 10 & 1945 & 24 & 615 & 12,398 & 152,340 & 56,712 & 125 & 2.3 & 6.2 \\
\hline 11 & 80 & $<0.1$ & 150 & 3558 & 86,400 & 25,090 & 154 & 0.78 & 6.9 \\
\hline 12 & 102 & $<0.1$ & 145 & 2987 & 82,123 & 23,456 & 112 & 0.63 & 7.1 \\
\hline 13 & 547 & 8 & 55 & 4632 & 15,580 & 3446 & 24 & 0.68 & 7.3 \\
\hline 14 & 589 & 10 & 72 & 3987 & 17,235 & 3558 & 21 & 0.57 & 7.5 \\
\hline $15^{*}$ & $<0.1$ & $<0.1$ & $<0.1$ & 77 & 14,110 & 198 & 290 & 0.032 & 6.4 \\
\hline $16^{*}$ & $<0.1$ & $<0.1$ & $<0.1$ & 101 & 12,786 & 201 & 205 & 0.028 & 6.7 \\
\hline 17 & 2260 & 12 & 871 & 10,710 & 149,690 & 40,698 & 39 & 1.5 & 6.2 \\
\hline 18 & 2124 & 15 & 912 & 11,456 & 152,345 & 38,245 & 21 & 1.9 & 6.4 \\
\hline 19 & 1096 & $<0.1$ & 747 & 18,160 & 163,200 & 24,330 & 23 & 2.2 & 6.0 \\
\hline 20 & 918 & $<0.1$ & 815 & 17,234 & 171,234 & 25,786 & 15 & 1.8 & 6.1 \\
\hline 21 & 288 & $<0.1$ & 881 & 10,063 & 126,146 & 45,670 & $<0.1$ & 1.2 & 6.8 \\
\hline 22 & 303 & $<0.1$ & 956 & 11,005 & 131,987 & 43,874 & $<0.1$ & 0.23 & 6.7 \\
\hline 23 & 1503 & 43 & 144 & 7656 & 26,184 & 2222 & 47 & 0.21 & 6.2 \\
\hline 24 & 589 & 26.1 & 122 & 4398 & 19,854 & 2419 & 84 & 1.7 & 6.4 \\
\hline 25 & 6144 & 101 & 859 & 7370 & 55,121 & 3884 & 7 & 1.1 & 6.0 \\
\hline average $* *$ & 1225 & 14 & 812 & 9933 & 115,337 & 31,600 & 42 & 1.34 & 6.5 \\
\hline median ** & 925 & 8 & 747 & 10,068 & 141,720 & 36,090 & 23 & 1.53 & 6.4 \\
\hline Max & 6144 & 101 & 3080 & 18,160 & 212,512 & 57,612 & 154 & 2.30 & 7.5 \\
\hline Min & 80 & 0 & 55 & 2987 & 15,580 & 2222 & 0 & 0.21 & 6.0 \\
\hline
\end{tabular}

${ }^{*}$ Blind Samples; ${ }^{* *}$ Statistical processing excludes blind samples i.e., 4, 4a, 8, and 8a.

Factors affecting metal retention and mobility in soils include $\mathrm{pH}$, initial metal concentration, soil sorption capacity, organic matter content, age of contamination, and the presence of different inorganic contaminants in soil [16]. 
Metal concentrations in our samples are extremely high (Table 2), posing a significant hazard for human health and the environment. Soil under consideration is characterized as unusually polluted according to ICRCL classification of soils (ICRCL, 2001-Table 3), especially for As, $\mathrm{Pb}$, and $\mathrm{Zn}$. Even for $\mathrm{Fe}$, which is not considered toxic, its high concentration may significantly deteriorate groundwater quality [17]. On the other hand, the age of the contamination renders soil-metal and metal-metal bounds less mobile due to the formation of numerous surface complexes of solids [11]. Moreover, the metal sorption capacity of soil is exceeded; conclusively, pollution is present as discrete metal-mineral phases and is not bound to specific soil components [18].

Table 3. Soil classification according to the presence of specific pollutants.

\begin{tabular}{cccccc}
\hline Element & $\begin{array}{c}\text { Uncontaminated } \\
\text { Soil }\end{array}$ & $\begin{array}{c}\text { Slight } \\
\text { Contaminated Soil }\end{array}$ & $\begin{array}{c}\text { Contaminated } \\
\text { Soil }\end{array}$ & $\begin{array}{c}\text { Heavy } \\
\text { Contaminated Soil }\end{array}$ & $\begin{array}{c}\text { Unusually Heavy } \\
\text { Contaminated Soil }\end{array}$ \\
\hline $\mathrm{Pb}(\mathrm{ppm})$ & $0-500$ & $500-1000$ & $1000-2000$ & $2000-10,000$ & 10,000 \\
$\mathrm{Zn}(\mathrm{ppm})$ & $0-250$ & $250-500$ & $500-1000$ & $1000-5000$ & 5000 \\
$\mathrm{Cd}(\mathrm{ppm})$ & $0-1$ & $1-3$ & $3-10$ & $10-50$ & 50 \\
$\mathrm{Cu}(\mathrm{ppm})$ & $0-100$ & $100-200$ & $200-500$ & $500-2500$ & 2500 \\
$\mathrm{As}(\mathrm{ppm})$ & $0-30$ & $30-50$ & $50-100$ & $100-500$ & 500 \\
\hline & & Source: [19].
\end{tabular}

Metals and metalloids concentrations are characteristic of slags rather than flotation or other type of metallurgical waste [12]. Moreover, soil $\mathrm{pH}$ was found to be slightly acidic to neutral (Table 1) while sulfur content was relatively low (below $2 \%$ in all samples). Those results indicate that waste mainly consists of slags, since flotation wastes contain much higher sulfur concentrations and their $\mathrm{pH}$ is usually significantly lower $[10,11,14]$.

Metallurgical slags are expected to have metals and metalloids mainly in forms of oxides [13-15], while the existence of sulfur compounds is rather rare, resulting in the presence of more stable metal forms and, consequently, in lower mobility of pollutants (under normal environmental conditions).

Leaching tests for selected samples were performed according to the Directive 2003/33/EC to characterize the nature of the deposited waste. The results showed low mobility of heavy metals (i.e., less than $0.5 \%$ of the total metal content).

\section{Risk Assessment Analysis}

In recent years, risk assessment and risk management techniques are increasingly being used to deal with environmental issues. In broad terms, risk assessment is carried out to examine the effects of an agent, estimated either quantitatively or qualitatively, on humans (Human Risk Assessment) and ecosystems (Ecological Risk Assessment). Risk management is defined as the process of evaluating and selecting appropriate regulatory or remedial alternatives [20]. Thus, contrary to soil standards that focus solely on soil remediation, risk assessment and management techniques may prove to be helpful in limiting risks to human health and the ecosystem to acceptable levels at an affordable cost.

The approach in this study follows the current U.S. Environmental Protection Agency guidance for conducting human health risk evaluations [21-23], which is widely accepted and used for more than two decades. The objective of the risk assessment analysis was to estimate the risks posed by the contaminated soil to the affected population, in order to define a cost effective, risk-based remediation scheme.

The case study risk assessment is presented in a step-by-step format, which is divided in four fundamental parts:
a. data collection and hazard evaluation
b. exposure assessment
c. toxicity assessment
d. risk characterization 
(a) Data Collection and Hazard Evaluation: In this step all the available data for the site are gathered and analyzed to identify risk sources, specific hazardous substances, etc. Focusing on soil, seven metals and metalloids (arsenic, cadmium, lead, copper, iron, zinc, and chromium) were selected for risk evaluation, because of their concentration, frequency of appearance, and the available toxicity parameter values.

(b) Exposure Assessment: The exposure assessment focuses on estimating a substance dose (chronic daily intake in $\mathrm{mg} / \mathrm{kg}$-day) to which individuals are exposed or are about to be exposed. The pollutant linkage is evaluated, in terms of the pathways, the routes of exposure, frequency, and duration of exposure and the susceptible population, based on the current and future land use scenario.

The Kavodokanos site consists mainly of open space land and a couple of dwellings and is located in close proximity to a residential area. It is intended to be used as a recreational site, therefore cancer and non-cancer risks are estimated both for visitors (recreationists) and residents. Non-cancer risks are estimated for children and adults separately. Three routes of exposure are examined: inhalation of soil particles, dermal contact, and oral intake (ingestion).

Default exposure parameters that represent Reasonable Maximum Exposure conditions for long-term exposure are mostly used in the analysis. These parameters are based on EPA's Risk Assessment Guidance for Superfund [23] and Soil Screening Guidance documents [24,25]. Human health risk to recreationists was estimated assuming 75 visits per year (Exposure frequency $\mathrm{EF}=75$ days /year), which is a conservative assumption, representing reasonable maximum exposure (RME) recommended by EPA [22]. It is considered both protective and reasonable since the site is always open to visitors and trespassers (there is no supervision or barriers such as fences) and in close proximity to the city of Lavrion. Since there is an amount of uncertainty in exposure frequency estimates and for comparison reasons, human health risk was also estimated for the unlikely scenario of a single visit to the site per year.

In order to deal with spatial heterogeneity in soil contamination and uncertainty in calculating the average concentration at the site, the $95 \%$ upper confidence limit (UCL) of the mean is calculated for each contaminant of concern, by means of the ProUCL software (Table 4). The 95\% UCL of the mean is recommended as a conservative estimate of the concentration likely to be contacted over time [26-28].

Table 4. 95\% UCL of the mean concentration (ppm).

\begin{tabular}{cccccccc}
\hline Contaminant & As & $\mathbf{C d}$ & $\mathbf{C u}$ & $\mathbf{P b}$ & $\mathbf{F e}$ & $\mathbf{Z n}$ & $\mathbf{C r}$ \\
\hline 95\% UCLs & 3.568 & 55,53 & 2.334 & 10.245 & 161.384 & 44.981 & 112,10 \\
\hline
\end{tabular}

The following general equation is used to estimate the exposure dose resulting from contact with each contaminant in soil:

$$
\mathrm{CDI}=\frac{\mathrm{C} \times \mathrm{CR} \times \mathrm{EF} \times \mathrm{ED}}{\mathrm{BW} \times \mathrm{AT}}
$$

where:

CDI: dose-chemical intake (mg/kg-day);

C: concentration of a substance in an environmental medium ( $\mathrm{mg} / \mathrm{unit})$;

CR: contact rate (units/day);

EF: exposure frequency (days/year);

ED: exposure duration (years);

BW: body weight $(\mathrm{Kg})$;

AT: average time (years).

(c) Toxicity Assessment: Toxicity assessment refers to dose-response evaluation. Toxicity values are used to describe the cancer and non-cancer health effects caused by differing levels of exposure (or doses) to a specific contaminant. Reference Dose (oral) and Reference Concentration (inhalation) 
refer to non-carcinogenic health effects, while Slope Factor (oral) and Unit Risk Factor (inhalation) refer to carcinogenic risk. Oral slope factor (SF) is an estimate of the increased cancer risk from oral exposure to a dose of $1 \mathrm{mg} / \mathrm{kg}$-day for a lifetime. The SF can be multiplied by an estimate of lifetime exposure (in $\mathrm{mg} / \mathrm{kg}$-day) to estimate the lifetime cancer risk (IRIS). Inhalation unit risk (URF) is an estimate of the increased cancer risk from inhalation exposure to a concentration of $1 \mu \mathrm{g} / \mathrm{m}^{3}$ for a lifetime. The IUR can be multiplied by an estimate of lifetime exposure (in $\mu \mathrm{g} / \mathrm{m}^{3}$ ) to estimate the lifetime cancer risk. Oral reference dose (RfD) is the amount of a chemical that one can ingest every day for a lifetime ( $\mathrm{mg} / \mathrm{kg}$-day), that is not anticipated to cause harmful non-cancer health effects. Inhalation reference concentration ( $\mathrm{RfC}$ ) is the concentration of a chemical that one can breathe every day for a lifetime that is not anticipated to cause harmful non-cancer health effects. The RfC can be compared to an estimate of exposure concentration in $\mathrm{mg} / \mathrm{m}^{3}$. Toxicity values, for use in EPA-recommended human health risk assessments, are available from several sources. The recommended hierarchy for these alternative sources is described in Human Health Toxicity Values in Superfund Risk Assessments [29]: The preferred source of toxicity data is EPA's Integrated Risk Information System (IRIS) database [30]. Values in this database have been derived by expert toxicologists at EPA and most values have undergone thorough review and validation both within and outside EPA. If toxicity values for a contaminant of potential concern are not available in IRIS, the next source to consult is EPA's Provisional Peer Reviewed Toxicity Values (PPRTVs). This source includes toxicity values that have been developed by the Office of Research and Development/National Center for Environmental Assessment/Superfund Health Risk Technical Support Center (STSC) [31]. Other Toxicity Values may be used, such as the California EPA (Cal/EPA)'s Toxicity Criteria Database Exit, the Agency for Toxic Substances and Disease Registry (ATSDR)'s Minimal Risk Levels (MRLs) for Hazardous Substances [32] and the toxicity values in EPA's Health Effects Assessment Summary Tables (HEAST) [33].

The toxicity parameters for chronic exposure and their relative sources that were used in our analysis are presented in Table 5.

Table 5. Toxicity parameters.

\begin{tabular}{ccccccc}
\hline Chemical & As & Cd & Cr & Cu & Fe & Zn \\
\hline RfD $(\mathrm{mg} / \mathrm{kg}$-day) & $3.00 \times 10^{-4}$ & $1.00 \times 10^{-3}$ & $3.00 \times 10^{-3}$ & $4.00 \times 10^{-2}$ & $7.00 \times 10^{-1}$ & - \\
Reference & IRIS & IRIS & IRIS & HEAST & PPRTV Current & $3.00 \times 10^{-1}$ \\
RfC $\left(\mathrm{mg} / \mathrm{m}^{3}\right)$ & $1.50 \times 10^{-5}$ & $1.00 \times 10^{-5}$ & $1.00 \times 10^{-4}$ & - & - & - \\
Reference & CALEPA & ATSDR Final & IRIS & & - \\
SF $(\mathrm{mg} / \mathrm{kg} \text {-day })^{-1}$ & 1.50 & - & $5.00 \times 10^{-1}$ & - & - & $8.50 \times 10^{-3}$ \\
Reference & IRIS & & NJEPA & & - \\
URF $\left(\mu \mathrm{g} / \mathrm{m}^{3}\right)^{-1}$ & $4.30 \times 10^{-3}$ & $1.80 \times 10^{-3}$ & $8.40 \times 10^{-2}$ & - & - & $1.20 \times 10^{-5}$ \\
Reference & IRIS & IRIS & RAIS & & - \\
\hline
\end{tabular}

(d) Risk Characterization: The final step of the risk assessment process is to quantify the potential for carcinogenic and non-carcinogenic impacts for all possible routes of exposure. U.S. EPA has established an acceptable hazard quotient (HQ) equal to 1, for non-carcinogenic effects, while the acceptable cancer risk, expressing the probability of an individual developing any type of cancer if exposed to carcinogenic agents during his or her lifetime, equals $1.0 \times 10^{-6}$. Hazard quotients and cancer risks for each contaminant and route of exposure are calculated using Equations (2)-(7) based on EPA's Risk Assessment Guidance for Superfund: Volume I, Parts A, E \& F [21,34,35].

(i) For carcinogenic effects due to soil ingestion:

$$
\text { Risk }=\mathrm{CDI} \times \mathrm{SF}
$$

(ii) For non-carcinogenic effects due to soil ingestion:

$$
\mathrm{HQ}=\frac{\mathrm{CDI}}{\mathrm{RfD}}
$$


(iii) For carcinogenic effects due to inhalation of particulates:

$$
\text { Risk }=\mathrm{CDI} \times \mathrm{URF}
$$

(iv) For non-carcinogenic risks due to inhalation of particulates:

$$
\mathrm{HQ}=\frac{\mathrm{CDI}}{\mathrm{RfC}}
$$

(v) For carcinogenic effects due to dermal contact:

$$
\text { Risk }=\frac{\mathrm{CDI} \times \mathrm{SF}}{\mathrm{GIABS}}
$$

(vi) For non-carcinogenic effects due to dermal contact:

$$
\mathrm{HQ}=\frac{\mathrm{CDI}}{\mathrm{RfD} \times \mathrm{GIABS}}
$$

where: GIABS stands for GastroIntestinal ABSorption factor. The GIABS value is used to convert oral slope factors (administered dose) to dermal slope factors (administered dose) by factoring out the percentage eliminated in bodily waste.

In order to quantify non-carcinogenic risk for multiple substances, an additive approach is used. In particular, the Hazard Index (HI) is defined as the sum of all Hazard Quotients:

$$
\mathrm{HI}=\Sigma \mathrm{HQi}
$$

where: HQi is the Hazard Quotient attributable to a single substance.

The same approach is followed for carcinogenic effects involving more than one chemical:

$$
\mathrm{Rt}=\Sigma \mathrm{Ri}
$$

where: $\mathrm{Rt}$ the total risk and $\mathrm{Ri}$ is the risk derived from the presence of a single substance.

Total risk is calculated by summation of all risks for each route of exposure, for cancer and non-cancer health effects, respectively.

\section{Results}

\subsection{Risk Assessment}

In the following Tables (Tables 6-11), risks associated with carcinogenic and non-carcinogenic effects through ingestion of soil, inhalation of particulates, and dermal contact are presented.

Table 6. Cancer risks posed to residents.

\begin{tabular}{ccccc}
\hline Cancer Risk & Ingestion & Inhalation & Dermal Contact & Total \\
\hline $\mathrm{As}$ & $4.62 \times 10^{-3}$ & $4.02 \times 10^{-6}$ & $6.50 \times 10^{-4}$ & $5.27 \times 10^{-3}$ \\
$\mathrm{Cd}$ & - & $2.62 \times 10^{-8}$ & - & $2.62 \times 10^{-8}$ \\
$\mathrm{Cu}$ & - & - & - & 0 \\
$\mathrm{~Pb}$ & $1.25 \times 10^{-4}$ & $3.22 \times 10^{-8}$ & - & $1.25 \times 10^{-4}$ \\
$\mathrm{Fe}$ & - & - & - & 0 \\
$\mathrm{Zn}$ & - & - & - & 0 \\
$\mathrm{Cr}$ & $8.06 \times 10^{-5}$ & $2.47 \times 10^{-6}$ & - & $8.31 \times 10^{-5}$ \\
Total & $4.82 \times 10^{-3}$ & $6.54 \times 10^{-6}$ & $6.50 \times 10^{-4}$ & $5.48 \times 10^{-3}$ \\
\hline
\end{tabular}


Table 7. Non-cancer risks posed to residents—adults.

\begin{tabular}{ccccc}
\hline Non-Cancer Risk-Adults & Ingestion & Inhalation & Dermal Contact & Total \\
\hline $\mathrm{As}$ & 8.55 & 0.17 & 1.81 & 10.53 \\
$\mathrm{Cd}$ & 0.07 & 0 & 0.01 & 0.08 \\
$\mathrm{Cu}$ & 0.07 & - & - & 0.07 \\
$\mathrm{~Pb}$ & - & - & - & - \\
$\mathrm{Fe}$ & 0.28 & - & - & 0.28 \\
$\mathrm{Zn}$ & 0.18 & - & - & 0.18 \\
$\mathrm{Cr}$ & 0.04 & 0 & - & 0.04 \\
Total & 9.19 & 0.17 & 1.82 & 11.18 \\
\hline
\end{tabular}

Table 8. Non-cancer risks posed to residents-children.

\begin{tabular}{ccccc}
\hline Non-Cancer Risk-Children & Ingestion & Inhalation & Dermal Contact & Total \\
\hline $\mathrm{As}$ & 91.24 & 0.17 & 10.83 & 102.24 \\
$\mathrm{Cd}$ & 0.71 & 0 & 0.07 & 0.78 \\
$\mathrm{Cu}$ & 0.75 & - & - & 0.75 \\
$\mathrm{~Pb}$ & - & - & - & - \\
$\mathrm{Fe}$ & 2.95 & - & - & 2.95 \\
$\mathrm{Zn}$ & 1.92 & - & - & 1.92 \\
$\mathrm{Cr}$ & 0.48 & 0 & - & 0.48 \\
Total & 98.03 & 0.17 & 10.89 & 109.09 \\
\hline
\end{tabular}

Table 9. Cancer risks posed to recreationists.

\begin{tabular}{ccccc}
\hline Cancer Risk & Ingestion & Inhalation & Dermal Contact & Total \\
\hline $\mathrm{As}$ & $9.90 \times 10^{-4}$ & $3.59 \times 10^{-8}$ & $1.39 \times 10^{-4}$ & $1.13 \times 10^{-3}$ \\
$\mathrm{Cd}$ & - & $2.34 \times 10^{-10}$ & - & $2.34 \times 10^{-10}$ \\
$\mathrm{Cu}$ & - & - & - & - \\
$\mathrm{Pb}$ & $2.68 \times 10^{-5}$ & $2.87 \times 10^{-10}$ & - & $2.68 \times 10^{-5}$ \\
$\mathrm{Fe}$ & - & - & - & - \\
$\mathrm{Zn}$ & - & - & - & - \\
$\mathrm{Cr}$ & $1.73 \times 10^{-5}$ & $2.20 \times 10^{-8}$ & - & $1.73 \times 10^{-5}$ \\
Total & $1.03 \times 10^{-3}$ & $5.84 \times 10^{-8}$ & $1.39 \times 10^{-4}$ & $1.17 \times 10^{-3}$ \\
\hline
\end{tabular}

Table 10. Non-cancer risks posed to recreationists—adults.

\begin{tabular}{ccccc}
\hline Non-Cancer Risk-Adults & Ingestion & Inhalation & Dermal Contact & Total \\
\hline $\mathrm{As}$ & 1.83 & 0.00 & 0.39 & 2.22 \\
$\mathrm{Cd}$ & 0.01 & 0.00 & 0.00 & 0.01 \\
$\mathrm{Cu}$ & 0.01 & - & 0.00 & 0.01 \\
$\mathrm{~Pb}$ & - & - & - & - \\
$\mathrm{Fe}$ & 0.06 & - & 0.00 & 0.06 \\
$\mathrm{Zn}$ & 0.04 & - & 0.00 & 0.04 \\
$\mathrm{Cr}$ & 0.01 & 0.00 & 0.00 & 0.01 \\
Total & 1.97 & 0.00 & 0.39 & 2.36 \\
\hline
\end{tabular}

Table 11. Non-cancer risks posed to recreationists—children.

\begin{tabular}{ccccc}
\hline Non-Cancer Risk-Children & Ingestion & Inhalation & Dermal Contact & Total \\
\hline $\mathrm{As}$ & 19.55 & 0.00 & 2.32 & 21.87 \\
$\mathrm{Cd}$ & 0.15 & 0.00 & 0.00 & 0.15 \\
$\mathrm{Cu}$ & 0.16 & - & 0.00 & 0.16 \\
$\mathrm{~Pb}$ & - & - & - & - \\
$\mathrm{Fe}$ & 0.63 & - & 0.00 & 0.63 \\
$\mathrm{Zn}$ & 0.41 & - & 0.00 & 0.41 \\
$\mathrm{Cr}$ & 0.10 & 0.00 & 0.00 & 0.10 \\
Total & 21.01 & 0.00 & 2.32 & 23.33 \\
\hline
\end{tabular}


Considering the risk assessment results, there is an excessive cancer risk for both residents and recreationists, more than three orders of magnitude over the acceptable risk level of $1.0 \times 10^{-6}$. Recreationists are exposed to excessive cancer risk, even in the case of a single visit to the site per year (Table 12).

There is also a high potential for non-cancer health effects for residents and frequent visitors and especially for the children living in the vicinity of the Kavodokanos site, who are exposed to a risk of adverse health effects more than 100 times higher than the acceptable limit (Tables 13 and 14).

With regard to the available toxicity values and the risk analysis results, As and $\mathrm{Pb}$ seem to be the most threatening contaminants. Still, the risk posed by the presence of $\mathrm{Cr}, \mathrm{Fe}$, and $\mathrm{Zn}$, in some cases, calls for a remediation scheme addressing multi-contaminated soil.

Table 12. Cancer risk posed to residents-recreationists.

\begin{tabular}{cccc}
\hline Route of Exposure & Residents & Recreationists (75 Visits/Year) & Recreationists (1 Visit/Year) \\
\hline Ingestion & $4.82 \times 10^{-3}$ & $1.03 \times 10^{-3}$ & $1.38 \times 10^{-5}$ \\
Inhalation & $6.54 \times 10^{-6}$ & $5.84 \times 10^{-8}$ & $7.79 \times 10^{-10}$ \\
Dermal Contact & $6.50 \times 10^{-4}$ & $1.39 \times 10^{-4}$ & $1.86 \times 10^{-6}$ \\
Total & $5.48 \times 10^{-3}$ & $1.17 \times 10^{-3}$ & $1.56 \times 10^{-5}$ \\
\hline
\end{tabular}

Table 13. Non-cancer risk posed to adults, residents-recreationists.

\begin{tabular}{cccc}
\hline Route of Exposure & Residents & Recreationists (75 Visits/Year) & Recreationists (1 Visit/Year) \\
\hline Ingestion & 9.19 & 1.97 & 0.03 \\
Inhalation & 0.17 & 0.00 & 0.00 \\
Dermal Contact & 1.82 & 0.39 & 0.01 \\
Total & 11.18 & 2.36 & 0.031 \\
\hline
\end{tabular}

Table 14. Non-cancer risk posed to children, residents-recreationists.

\begin{tabular}{cccc}
\hline Route of Exposure & Residents & Recreationists (75 Visits/Year) & Recreationists (1 Visit/Year) \\
\hline Ingestion & 98.03 & 21.01 & 0.28 \\
Inhalation & 0.17 & 0.00 & 0.00 \\
Dermal Contact & 10.89 & 2.32 & 0.03 \\
Total & 109.09 & 23.33 & 0.31 \\
\hline
\end{tabular}

Ingestion is the most critical pathway, followed by dermal contact (Figures 1-3). Non-cancer inhalation risk is below the threshold, whereas the cancer risk posed to residents via inhalation is considered acceptable, since it is based on conservative assumptions.

Although the risk analysis is based on default values and conservative assumptions, and the chemical daily intake might be lower (especially if safety measures are taken) the risk results are too high not to raise concerns about the safety of the population exposed.

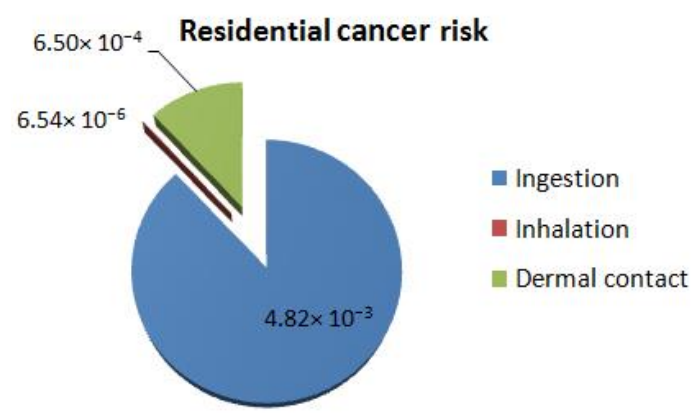

Figure 1. Contribution of each pathway to residential cancer risk. 
Residential non-cancer risk (adults)

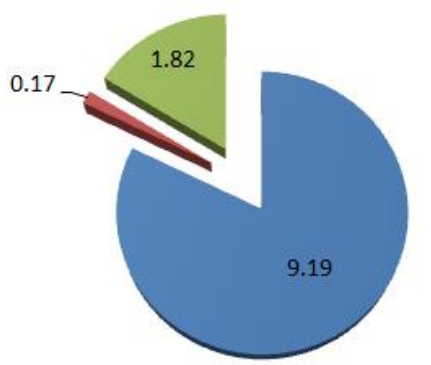

Ingestion

- Inhalation

- Dermal contact

Figure 2. Contribution of each pathway to residential non-cancer risk (adults).

\section{Residential non-cancer risk (children)}

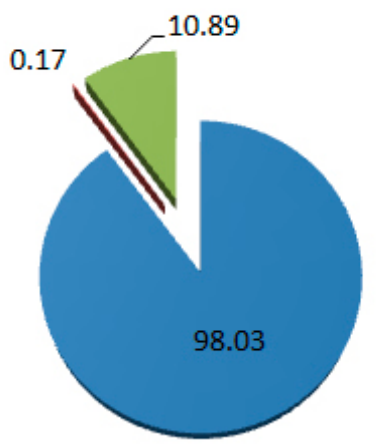

- Ingestion

- Inhalation

Dermal contact

Figure 3. Contribution of each pathway to residential non-cancer risk (children).

\subsection{Risk Management}

Using the risk-based approach to explore cost-effective management alternatives requires understanding the mechanism by which contamination from a given source can reach the exposed receptors. The ways in which the susceptible population is exposed to contamination in the case of the Kavodokanos site is depicted in the conceptual model of Figure 4 and can be used to provide an overall understanding of the problem, along with the risk assessment results.

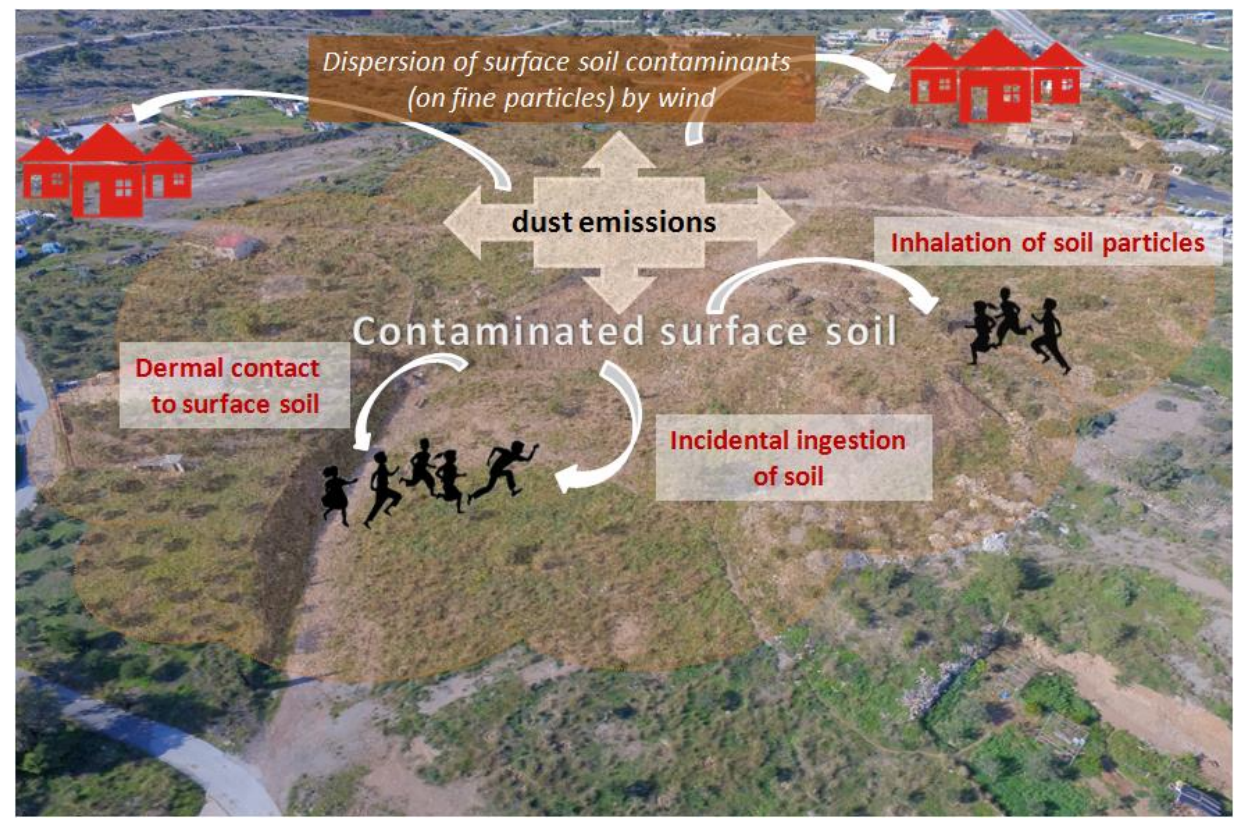

Figure 4. Kavodokanos conceptual site model. 
Since there are no volatile chemicals in the soil and the risk caused by inhaling soil particulates is relatively low, inhalation exposure is of no particular concern. Still, the airborne fine particles of contaminated topsoil can disperse by wind in a larger area and migrate to indoor dust. Moreover, given that mine waste at Kavodokanos site has low mobility and groundwater is not used for drinking or other domestic purposes, no risks are posed to receptors via this pathway. All in all, with regard to the current and future land use of the site, concerns are expected to rise only from contaminated topsoil, mainly through incidental ingestion or dermal contact.

With regard to risk analysis, human health risks can be reduced to acceptable levels by breaking the pollutant linkage. There are three ways to achieve that:

i. Source control: Using a combination of treatment technologies to address the presence of multiple contaminants in the soil.

ii. Pathway Management: Using engineering controls (e.g., containment) to prevent exposure.

iii. Receptor protection: Altering the behavior/presence of receptors, modifying land use.

Bearing in mind the site-specific characteristics it is rather difficult to constrain the presence of receptors. As regards the control of the source, the remediation cost using treatment technologies would be more than 20 million Euros. Therefore, considering the available funds, the application of treatment technologies over the entire area would be completely prohibitive. The latter stands also for the excavation and containment of the waste, since the estimated cost would be at least 15 million Euros and could climb even higher, even if an appropriate site existed in the surrounding area. In addition, using treatment techniques would jeopardize the opportunity to recover valuable resources in the future.

To this end, the decision was to implement countermeasures that would break the second link in the chain "Contaminated topsoil due to mine waste $\rightarrow$ Ingestion \& dermal contact $\rightarrow$ Humans". Covering the site surface would break the link between the pathway (ingestion and dermal contact) and the target (humans). Thus, a multi-layer cover system was designed including the following components (top to bottom):

- A top layer of at least $1 \mathrm{~m}$ soil, possibly vegetated (depending on the end use of the remediated site)

- A granular or geosynthetic drainage layer with a hydraulic transmissivity of no less than $3 \times 10^{-5} \mathrm{~cm}^{2} \cdot \mathrm{s}^{-1}$

- A low permeability layer comprised of compacted soil with a hydraulic conductivity no greater than $1 \times 10^{-7} \mathrm{~cm} \cdot \mathrm{s}^{-1}$. Additionally, a flexible HDPE membrane liner may be implemented (above the compacted soil) for higher protection

The proposed remediation scheme presents significant advantages:

- It shields humans and natural ecosystems from the harmful effects of the deposited mine waste at an affordable cost (about 1.5 million Euros);

- It allows the safe use of the site for recreational purposes;

- It increases the potential to re-mine the accumulated mining wastes, since they will remain intact under the multilayer covering system.

\section{Discussion and Conclusions}

Contaminated mined land is a problem that deserves emergency attention due to its magnitude and impacts on human health and the environment. Existing soil conservation policies and legislation are based almost solely on limit values for certain contaminants, which can be achieved only by means of soil remediation techniques. Nevertheless, soil remediation is not always possible due to the prohibitive costs incurred. In such cases, risk-based approaches may be a much more useful decision-making tool. 
For instance, in the case studied, the results of risk assessment analysis showed that immediate measures have to be taken in order to protect human health, either by source elimination or by pathway management (e.g., by using a barrier to prevent exposure to contaminants). To meet international standards for site remediation by eliminating the source of the hazard via typical remediation techniques would require a cost 4-6 million Euros, according to Table 1. Provided that: (a) available funds are insufficient to permit treatment of all contaminated soil; (b) the site is already being used as recreational open space and, in addition, the surrounding area has a residential character; and (c) source elimination would eliminate not only the risks but also the opportunities to create value in the future by re-using the mine waste, then the remediation plan should be suitable for breaking the link between the routes of exposure and the susceptible population. To this end, it proposes the construction of an upper sealing layer, the installation of the drainage system and the placement of the topsoil since, according to the geological structure, leakages were expected from the substratum.

Although risk assessment estimates are subject to uncertainty, the risk-based approach provided a formal basis to evaluate and rank potential hazards with respect to a branch of factors (e.g., economic, social, political). Moreover, it highlighted and prioritized local conditions and needs, and directed the proposed solution towards the most suitable site- and time-specific actions so as to make the site safe for its users, until technological advancements and economic developments make the recovery of stored materials feasible. Finally, risk assessment assimilates different kinds of technical and non-technical information, helps all parties involved (e.g., competent authorities, site managers, and the public) understand the true dimensions of the problem, and thus minimizes any delays in the remediation actions required.

Acknowledgments: This work was supported by the Municipality of Lavrion in the context of the project "Technical study for the remediation and redevelopment of Kavodokanos disposal site".

Author Contributions: T.K. performed and reported risk assessment estimates; V.P. performed chemical analyses and reported the results; D.K. conceived and described the management approach; M.M. coordinated the work and summarized the results and the conclusions of the research.

Conflicts of Interest: The authors declare no conflict of interest.

\section{References}

1. Van Liedekerke, A.; Prokop, G.; Rabl-Berger, S.; Kibblewhite, M.; Geertrui Louwagie, G. Progress in the Management of Contaminated Sites in Europe; JRC Reference Reports, Report EUR 26376 EN; European Commission, Joint Research Center: Luxembourg, 2014.

2. Panagos, P.; Van Liedekerke, M.; Yigini, Y.; Montanarella, L. Contaminated Sites in Europe: Review of the Current Situation Based on Data Collected through a European Network. J. Environ. Public Health 2013, 2013, 158764. [CrossRef] [PubMed]

3. European Environment Agency. Europe's Environment: The Dobris Assessment; European Environment Agency, Office des Publications: Luxembourg, 1998; p. 676.

4. Contaminated Land Rehabilitation Network for Environmental Technologies. Remediation of Contaminated Land Technology Implementation in Europe; Department for Environment Food and Rural Affairs (DEFRA), Federal Environment Agency: Vienna, Austria, 2002.

5. Kaliampakos, D.; Damigos, D.; Karachaliou, T. Using the "dry-tomb" technique in the remediation of heavily contaminated land. In Proceedings of the 10th International Symposium on Environmental Issues and Waste Management in Energy and Mineral Production (SWEMP 2007), Bangkok, Thailand, 11-13 December 2007; pp. 375-389.

6. U.S. Environmental Protection Agency. Remediation and Characterization Innovative Technologies-EPA REACH IT; U.S. Environmental Protection Agency, Technology Innovation Office: Arlington, VA, USA, 2000.

7. Kapur, A.; Graedel, T.E. Copper mines above and below ground. Estimating the stocks of materials in ore, products, and disposal sites opens up new ways to recycle and reuse valuable resources. Environ. Sci. Technol. 2006, 40, 3135-3141. [CrossRef] [PubMed] 
8. Frändegård, P.; Krook, J.; Svensson, N.; Eklund, M. A novel approach for environmental evaluation of landfill mining. J. Clean. Prod. 2013, 55, 24-34. [CrossRef]

9. Cairney, T. The Re-Use of Contaminated Land; John Willey \& Sons Ltd.: Chichester, UK, 1995; pp. $25-31$.

10. Konofagos, K. The Ancient Lavrion and the Greek Technique for Silver Production; Ekdotiki Ellados Publishing: Athens, Greece, 1980. (In Greek)

11. Moutsatsou, A.; Gregou, M.; Matsas, D.; Protonotarios, V. Washing as a remediation technology applicable in soils heavily polluted by mining-metallurgical activities. Chemosphere 2006, 63, 1632-1640. [CrossRef] [PubMed]

12. Xenidis, A.; Komnitsas, K.; Papassiopi, N.; Kontopoulos, A. Environmental Implications of the Mining Activities in Lavrion. In Proceedings of International Symposium on Engineering Geology and the Environment, Athens, Greece, 23-27 June 1997; Volume 3, pp. 2575-2580.

13. Demetriades, A.; Stavrakis, P.; Vergou-Vichou, K.; Makropoulos, V.; Vlachoyiannis, N.; Fosse, G. Lead in the surface soil of Lavreotiki peninsula (Attiki, Greece) and its effects on human health. In Proceedings of 3rd International Conference on Environmental Pollution, Aristotelean University of Thessaloniki, Thessaloniki, Greece, 16-19 September 1996; pp. 143-146.

14. Kontopoulos, A.; Komnitsas, K.; Xenidis, A. Environmental characterization of lead smelter slags in Lavrion. In Proceedings on Minerals, Metals and the Environment II, Prague, Czech Republic, 3-6 September 1996; pp. 405-419.

15. Moutsatsou, A.; Karathanasis, A.; Protonotarios, V. Remediation of soils polluted by industrial activities utilizing hydrothermally treated calcareous fly ashes. In Waste Management and the Environment II; WIT Press: Southampton, UK, 2004; pp. 283-291.

16. Reed, B.E.; Carriere, P.C.; Moore, R. Flushing of a Pb (II) contaminated soil using $\mathrm{HCl}, \mathrm{EDTA}$ and $\mathrm{CaCl}_{2}$. J. Environ. Eng. 1996, 121, 48-50. [CrossRef]

17. Mulligan, C.N.; Yong, R.N.; Gibbs, B.F. Remediation Technologies for metal-contaminated soils and groundwater: An evaluation. Eng. Geol. 2001, 69, 193-207. [CrossRef]

18. Peters, R.W. Chelant extraction of heavy metals from contaminated soils. J. Hazard. Mater. 1999, 66, 151-210. [CrossRef]

19. ICRCL (Interdepartmental Committee for the Redevelopment of Contaminated Land). Guidance Note 59/83, 2nd ed.; Department of the Environment: London, UK, 1987.

20. National Research Council; Committee on the Institutional Means for Assessment of Risks to Public Health; Commission on Life Sciences. Risk Assessment in the Federal Government: Managing the Process; National Academy Press: Washington, DC, USA, 1983.

21. U.S. Environmental Protection Agency. Risk Assessment Guidance for Superfund: Volume 1-Human Health Evaluation Manual (Part A); Interim Final, EPA/540/1-89/002; U.S. Environmental Protection Agency, Office of Emergency and Remedial Response, Development: Washington, DC, USA, 1989.

22. U.S. Environmental Protection Agency. Risk Assessment Guidance for Superfund: Volume 1-Human Health Evaluation Manual, Supplemental Guidance: Standard Default Exposure Factors; OSWER Directive 92985.6-03; U.S. Environmental Protection Agency, Office of Solid Waste and Emergency Response, Development: Washington, DC, USA, 1991.

23. U.S. Environmental Protection Agency. Risk Assessment Guidance for Superfund: Volume 1-Human Health Evaluation Manual (Part B, Development of Risk-Based Preliminary Remediation Goals); Interim, EPA/540/R-92/003; U.S. Environmental Protection Agency, Office of Research and Development, Development: Washington, DC, USA, 1991.

24. US Environmental Protection Agency. Soil Screening Guidance: User's Guide; Office of Solid Waste and Emergency Response: Washington, DC, USA, 1996.

25. US Environmental Protection Agency. Supplemental Guidance for Developing Soil Screening Levels for Superfund Sites; EPA, Office of Solid Waste and Emergency Response: Washington, DC, USA, 2002.

26. US Environmental Protection Agency. Guidelines for Exposure Assessment; Office of Research and Development, Office of Health and Environmental Assessment: Washington, DC, USA, 1992.

27. US Environmental Protection Agency. Calculating Upper Confidence Limits for Exposure Point Concentrations at Hazardous Waste Sites; Office of Emergency and Remedial Response: Washington, DC, USA, 2002. 
28. Department for Environment, Food and Rural Affairs. Assessment of Risks to Human Health from Land Contamination: An Overview of the Development of Soil Guideline Values and Related Research, CLR7; Department for Environment, Food and Rural Affairs, The Environment Agency: London, UK, 2002.

29. US Environmental Protection Agency. Human Health Toxicity Values in Superfund Risk Assessments; OSWER Directive 9285.7-53; Office of Solid Waste and Emergency Response, U.S. Environmental Protection Agency: Washington, DC, USA, 2003.

30. U.S. Environmental Protection Agency, Office of Research and Development. Integrated Risk Information System-IRIS, On-Line Database. Available online: http:/ / www.epa.gov/iris (accessed on 26 February 2016).

31. Environmental Protection Agency. Provisional Peer Reviewed Toxicity Values for Superfund (PPRTV). Available online: http:/ /hhpprtv.ornl.gov/ (accessed on 26 February 2016).

32. Agency for Toxic Substances and Disease Registry, Division of Toxicology. ATSDR ToxFAQs, On-Line Database. Available online: http:/ /www.atsdr.cdc.gov/ (accessed on 26 February 2016).

33. US Environmental Protection Agency. Health Effects Assessment Summary Tables (HEAST); U.S. Environmental Protection Agency: Washington, DC, USA, 1997.

34. U.S. Environmental Protection Agency. Risk Assessment Guidance for Superfund: Volume I-Human Health Evaluation Manual (Part E, Supplemental Guidance for Dermal Risk Assessment (Final); OSWER Directive 9285.7-02EPO; Office of Superfund Remediation and Technology Innovation, U.S. Environmental Protection Agency: Washington, DC, USA, 2004.

35. U.S. Environmental Protection Agency. Risk Assessment Guidance for Superfund: Volume I-Human Health Evaluation Manual (Part F, Supplemental Guidance for Inhalation Risk Assessment (Final); OSWER Directive 9285.7-82; Office of Superfund Remediation and Technology Innovation, U.S. Environmental Protection Agency: Washington, DC, USA, 2009.

(C) 2016 by the authors; licensee MDPI, Basel, Switzerland. This article is an open access article distributed under the terms and conditions of the Creative Commons Attribution (CC-BY) license (http:/ / creativecommons.org/licenses/by/4.0/). 